\title{
The Unification of differences
}

\author{
Stefan Freytag \\ International Master in Peace, Conflict and Development Studies of the University of Jaume I (UJI), \\ Castellón, Spain \\ UNESCO Chair of Philosophy for Peace \\ Tel +34 964729380 ,
}

E-mail address: Bergele@gmx.at ,epd@uji.es

Die Welt istimWandel ${ }^{1}$

\begin{abstract}
In this paper, I discuss the evolving idea of the "One World" as articulated in Wolfgang Sachs' article (1992), which was derived from the principles of the 1945 UN Charter. The paper also presents an insightful discussion on the recent crisis of perception in the three 'world regions' which are dominating the development discourse i.e. the Unites States, Europe and China. It argues that this is primarily a crisis of perception; "the world has turned into a mirror, which reflects a reality of us, which is constructed by experts of the system". It argues that placeless cultural knowledge has transformed our reality into a reality which lacks a place. We are stuck in our space - centered belief systems and we are everywhere and nowhere at the same time. The paper concludes that universalism has made us to be alone in space, knowing about the whole world, but at the same time unable to feel the connection to this world. We have lost presence, the ability to perceive our body and therefore the relation to the earth.
\end{abstract}

Keywords: Differences; Unification; Universalism; Peace; Diversity; Culture; Development

\section{INTRODUCTION}

"We have high inflation and unemployment, we have an energy crisis, a crisis in health care, pollution and other environmental disasters, a rising wave of violence ... these are all different facets of one and the same crisis that ... is essentially a crisis of perception" (Capra, $1982,1)$. This crisis of perception and loss of flexibility i.e. rigidity of social structure and behavior pattern (Toynbee in Capra, 1982, 8), are arguably a result of unification of differences or the "evaporation of cultures" (Sachs, 1992, 111). In this paper, I discuss the evolving idea of the "One World" (Sachs, 1992) which got started with the principles of the 1945 UN Charter and is still ongoing. I then talk about the recent crisis of perception in three 'world regions', which are dominating the development discourse i.e. the Unites States, Europe and China. In addition, I present a peace model which is informed by the "discovering and prescribing of universalized needs" (Illich, 1990, 3). I also elaborate on a "world of systems and ascriptions' and its impact on the perception of 'one-self' and its danger for a concept of 'many peaces.

\footnotetext{
${ }^{1}$ The world is in change
} 


\section{ONE WORLD}

How did this contradictory concept evolve? Could this be an attempt to unify mankind? In his article "One World", Wolfgang Sachs makes an analysis of the notion of unification of differences or universalism. According to Wolfgang Sachs, the vision of one mankind can be traced to the Charter of the United Nations in 1945 in the aftermath of World War II. The aim was to prevent war and national egoism in a bid to launch a new era of peace within a united mankind. The thinking of the victorious powers was that violence occurs when progress is blocked whereas peace is realized through progress and development. The linear expectation was that peace would be the result of mankind reunited under the achievement of civilization. The differences of 'cultures less civilized' that contradicted the idea of a united mankind "was resolved by interpreting the multiplicity of cultures in spaces as a succession in stages in time" (Sachs, 1992, 112). A worldwide program of stimulating growth and progress in the less developed areas of the world (under the banner of development) was therefore initiated, with the aim of "absorbing the differences in the world into a historical and delocalized universalism" (Sachs, 1992, 114). The globalization of market relationships was seen as the guarantee for peace. The idea was that wealth derives from exchange which creates mutual interest thus creating a dependency which overcomes violence. Wolfgang Sachs identifies several dilemmas associated with push for universalism. First is the perception that peace implies the evaporation of diversity, while the search for diversity is a recipe for violence. The other dilemma relates to the notion of the market and the constant push for growth as medium of unification which generates competition and the fear by government of falling behind in this competition. According to Wolfgang Sachs, it seems that there is no country that is able to control its own destiny. Fear dominates politics at all levels, and drives countries into exploitation of other states but also into self exploitation. Consequently, "mobilizing for competition means streamlining a country; diversity becomes an obstacle to be removed" (Sachs, 1992, 116). In his opinion this dilemma can only be transformed by de-linking progress from peace.

Recent debates on climate change have also been exploited to advance the argument for interconnection, and generated a new kind of dependency and responsibility under the guise of preventing "global self-destruction." The notion that local actions can affect the conditions of life in other places on the globe has been used to mobilize support for universalism project. Consequently people are not only linked by "the rule of civilization and the interplay of demand and supply, but their shared dependence of bio-physical life-support systems" (Sachs, 1992, 118). Thus, the world is preoccupied with the motive of saving the planet-where autonomy is regarded as anti-social behavior and diversity to an obstacle for united action.

\section{A WORLD IN CRISIS}

This section focuses on an analysis of three "world regions" that represent a what Illich $(1980,176)$ calls "paxeconomica" i.e. a balance between formally "economic" powers, and the inherent contradictions in the vision of peace out of growth universal rights and values. Particularly, I discuss issues related to: poverty and the loss of hope in the United States; Europe's instance on human rights that are broken at its own borders; and how China seems to forget its human values in its pursuit of wealth. 


\section{THE UNITED STATES}

My father was the first Austrian student to study at University of New Orleans, Louisiana. His best friends are still all in United States (US), but he recently indicated that he has no desire at all to visit them. He keeps telling me that the energy has changed: the hope, optimism and confidence, which have always been part of US are gone. And that is exactly what I experienced when I visited California in 2010, which for me is the flagship of the "American Dream" i.e. no matter who you are, you can make it. The self confidence and pride associated with the US were hardly visible..

"Die Zeit", a prominent German Newspaper, published an article in October 2011, Dealing with Life in the City of Los Angeles in California. The author, Jana Simon, describes it as the place where all the Western longing is concentrated. But it is the longing for a dream which may not exist anymore. The city is living for the moment: there is no respect for the past and no hope for the future. Everyone is on the move and therefore the present is treated like a place you leave very early again. If people leave the city they throw away all their furniture in order "to start all over again" (Simon, 2011, 14-20). And there is poverty. Every sixth American is suffering from hunger. There are thousands of homeless people living in the Streets of Los Angeles. If you ask why, the cynical answer is that they want to live like this. Many shops are empty, and in others you can see signs saying "we also accept food stamps". As life takes place in the moment, you are only liable for yourself. Subsequently relations are less and less valuable. You do not need to have compassion or care for people, because you are constantly on the move - everyone is about to leave the city - nobody wants to become old here. People are free but alone. What unites people is only the common fear of the future (ibid).

The suggestion that peace is achieved through growth (Sachs, 1992) is challenged by the situation in the US now. America has always been shaped more by the idea of the freedom of the individual than by the idea of solidarity (ibid.). But if the context changes, if there is a crisis, this does not work anymore. The vision of the universal applicable market value seems to have reached its limits.

\section{EUROPE}

Europe is facing another facet of the same change, but it is also suffering a crisis of values. The European Union (EU) is defending its borders against those who are seeking asylum and protection. Thousands of people die on their way to Europe (Fortress Europe, 2011). By empowering military institutions like Frontex, the EU fights with war technology to keep refugees out. Ceuta and Melilla in Spain, the River Evros in Greece, the Mediterranean and the West African coastline (Borderline Europe, 2011) are some of the battlefields between Europe and those who want to immigrate.

The battle is active and passive. Before the breakdown of the Gaddafi Regime, Italy was deporting refugees from their sovereign territory back to Libya thereby violating the non refoulment $^{2}$ regulations of International Law. It was deporting refugees back to Libya, a country with no asylum system and a high risk of human rights violation. Italy was systematically violating human rights with no interventions from the European Union (Europaeisches Parliament, 2010).

\footnotetext{
${ }^{2}$ Non-refoulment is a principle in international law that concerns the protection of refugees from being returned to places where their lives and freedoms could be threatened.
} 
The passive way of war is the absence of help. During the NATO attacks on Libya in March and April 2011, a vessel with 72 refugees, men, women and children was left to drift in open waters for 16 days in a high surveillance war zone. 61 people died from thirst and hunger. There were alarms raised in Rome and the Italian coastguard was informed, there was contact with a helicopter and with a warship, but no rescue was attempted. On the 10th of April the vessel was washed again to the shore of Libya. The English newspaper, The Guardian claims that in April 2011 alone more than 800 migrants of different nationalities left Libya by boat and never made it to the European coasts (Shenker, 2011).

In my experience, the identity of the European Union is shaped by a value system (e.g. Human Rights). Those values are spread around the world but broken at its borders simultaneously. The exclusion of refugees inside the European societies and at its material borders reveal the contradiction that the earth is perceived as one "but the world is not" (Sachs, 1992, 117).

\section{CHINA}

I move my focus now from the center of Universalist worldviews to a country which is probably the purest form of capitalist free market economy. I will talk about an accident which recently happened in China and which in my point of view questions the market mechanism as a gateway for peace.

On October 13, 2011, a two year old child was knocked down by an unknown driver who kept on driving. Seven minutes later, another car rolled over the child. Further, eighteen people passed-by until an old woman stopped and screamed for help. Everything was captured by a surveillance camera. Ever since, China has doubted itself. Most of the Chinese were appalled, and different surveys indicated that between 50 and 90 percent of the interviewed people would have helped.

However, the negation of help is justified by fear of getting in trouble. Nobody believes in the justice system or in the police anymore. People feel insecure and ask therefore "how can we protect others if we cannot protect ourselves" (Koeckritz, 2011). Even the communist party is promoting values, which are being corrupted by its members (ibid).

\section{A DEEPER UNDERSTANDING}

To gain a deeper understanding of the problems that have plagued societies that are, purportedly, united through common dreams, value systems and market participation, further reference is made to notion of "One World" and Ivan Illich's approach of universal needs.

\section{UNIVERSALISM}

Driven by science and market, universalism is against the notion of diversity. Universalism is based on a knowledge which claims to be valid everywhere: it belongs nowhere and can therefore infiltrate everywhere. Consequently Universalism is capable of "unsettling" all different kinds of cultures, since they are connected to particular places "with their own peoples, memories and cosmologies" (Sachs, 1992, 120). Wolfgang Sachs talks about the physical body which is the necessary connection to one place. The experience of 
man evolves from a certain place where the body is placed. "Having a memory, relating to other persons, participating in a larger story, calls for involvement, requires a presence" (ibid, 121). This presence is in my point of view corrupted by what Ivan Illich calls needs.

\section{NEEDS}

According to Ivan Illich, the western historical process under the banner of development and growth started after World War II, discovered and then prescribed needs. Before that period of time, to be human meant submission under the rule of necessity in a certain place at a certain time. Each culture translated this necessity of living into a different language. And each perspective on necessity was expressed in different ways "like burying the dead and exorcising fears". An enormous variety of cultures expressed desire and longing in different ways. But Ivan Illich emphasizes that nothing "indicates that the ancestral half of humanity experienced anything of what we take for granted under the designation of needs" (Illich, 1990, 3). He is talking about the dependence on services and goods, which we take as granted. He also makes the important distinction between necessity and need. Necessities call for submission, needs for satisfaction. "Needs attempt to deny the necessity to accept the unavoidable remoteness between wish and fact" (ibid).

For him, the human phenomenon is no longer defined by what we face, what we can take or what we dream, nor by the myth that we can produce ourselves out of scarcity, but by the measure of what we lack and therefore need. And these needs are offered, legitimated and prescribed by professionals in a universal system (ibid, 5 ).

\section{UNIVERSALIZED NEEDS?}

Need are relative, because satisfaction is relative. Experience of the need is also relative, and the means of meeting the needs are also relative.....

\section{A CORRUPTED PERSPECTIVE}

Values and knowledge, applicable everywhere, and needs which are described as universal needs, are missing place and context. They claim validity in all places. Wolfgang Sachs calls them concepts of space. And he adds that nobody is able to live only in space. Everyone lives as well in place, in a physical body. But this body also needs presence, the way a human is relating to its environment (Sachs, 1990, 121).

My hypothesis is now that this presence is corrupted by "space - centered" values and universal needs. The presence of a human body is defined by its connection with its environment. And this connection is in my perspective dependent on a mind which is focused on the body. But the mind seems to be occupied by needs, which are dependent on a market and its services and goods. I am affirming that this absence of the presence in our bodies is enabling experts of the prevailing belief system (doctors, politicians, sociologists) to define our needs. I think what Fritjof Capra describes as a crisis of perception; can also be called a lack of capability to perceive our bodies` own needs. 


\section{DISEMBODIMENT}

In my perspective, the development discourse did not only artificially create lesscivilized cultures, but also made us, the "civilized" society, believe in the superiority of our life model. A life model, which "divides what is indivisible - the wholeness of the human family; and unites what is not really unitable" (Bohm in Rosado, 2008, 2082). It has divided and still divides and classifies the world into constructed measurements of realities (e.g. Development Index), made visible through technological advancement. Consequently it still describes and promotes absolute values and strategies. The media is representative for this concept of space - centered knowledge. We are able to watch the world from above. Information is shared and transmitted within seconds - but therefore apparition is not necessarily bound to the existing any more. The media's anchor man is the mechanistic evidence of this process of "disembodiment" of our world (Berger, 2005, 12). If there are no bodies, there is no necessity because necessity is the precondition for all existing things (ibid, 12). But the myth of our system asks for that "what is not real yet", the virtual, the impulse to buy. In the end this process does not have the expected effect of freedom (freedom of choice), but only that of a profound isolation (ibid).

\section{CONCLUSION}

In my observation, the situations in all the different countries have a meeting point which is the isolation of the individual. The acceptance of space - centered thinking patterns is leading directly to the observer's perspective of oneself. The perception of oneself is not based on the individual experience in the face of the necessity to live, but in the mirror provided by the system. It is primarily a crisis of perception, because if we talk about ourselves, we repeat, what is described in icons, figures and indexes. The world has turned into a mirror, which reflects a reality of us, which is constructed by experts of the system. Placeless cultural knowledge has transformed our reality into a reality which lacks a place. We are stuck in our space - centered belief systems and we are everywhere and nowhere at the same time. We are alone in space, knowing about the whole world, but at the same time unable to feel the connection to this world. We have lost presence, the ability to perceive our body and therefore the relation to the earth. Living only for the moment in the US, with no respect for the past and fear of the future - thumping values which are simultaneously broken in Europe - and failing to notice people dying in front of your feet in China is for me a crisis of perception. The body is not perceived any more, but attributed by a space - centered system. All the mental and material power is inherent in our body. With the loss of perceiving our body we give the power away to influence the world. And as Ivan Illich writes: "without the possibility to create, it is nonsense to talk about responsibility. My moral responsibility has only the scope of my influence" (Illich, 2006, 189). 


\section{References}

[1] Berger John, Gegen die Abwertung der Welt. Essays. Frankfurt am Main, Fischer TaschenbuchVerlag, 2005.

[2] Borderline Europe Menschenrechteohne Grenzen, 2011). Available at URL: http://borderline-europe.de/index.php, last accessed February 07th 2012.

[3] Capra Fritjof, The Turning Point: Science, Society, and the Rising Culture, Simon and Schuster, 1982.

[4] Europaeisches Parlament, "Schriftliche Anfrage von David-Maria Sassoli (S-D), GianlucaSusta (S-D), Rita Borsellino (S-D) und Silvia Costa (S-D) an die Kommissionvom 14, September 2009". available at URL: http://www.europarl.europa.eu/sides/getDoc.do? type=WQ\&reference=E-20094327\&language $=$ DE, last accessed November 18th 2011.

[5] Fortress Europe, "List of 15551 documented refugee deaths through Fortress Europe, 2011. Available at URL: http://www.unitedagainstracism.org/pdfs/listofdeaths.pdf, last accessed November 18th 2011.

[6] Ivan Illich, "Peace vs. Development" in: Dietrich, Wolfgang and others (Eds.): Schluesseltexte der Friedensforschung, Wien/Berlin, Lit Verlag, (1980- 1990): "Needs", available at URL: http://www.surrenderworks.com/ivanillich/1990_needs.pdf, last accessed November 18th 2011.

[7] - (2006): In den Fluessennoerdlich der Zukunft. LetzteGespraecheueber Religion und Gesellschaftmit David Cayley.Muenchen, C.H Beck Verlag, authors Translation

[8] Koeckritz Angela, "YueyuesTod, Die Zeitvom”; October 2011, N 44.

[9] Rosado Caleb, "Context determines content: Quantum Physics as a Framework for "Wholeness" in Urban Transformation", Urban Studies 45(10) (2008) 2075-2097.

[10] Sachs Wolfgang and Dietrich et al, “One World”, in: (Eds.): Schluesseltexte der Friedens forschung, Wien/Berlin, Lit Verlag, 1992.

[11] Shenker Jack, "Aircraft carrier left us to die, say migrant, Exclusive: Boat trying to reach Lampedusa was left to drift in Mediterranean for 16 days, despite alarm being raised", the Guardian, 2011. Available at URL:

http://www.guardian.co.uk/world/2011/may/08/nato-ship-libyanmigrants?CMP=twt_gu, last accessed November 18th 2011.

[12] Simon, Jana, "Mein armesAmerika",ZeitMagazin Nr.44, October 27th 2011. 